\title{
Youth and human immunodeficiency virus infection and acquired immune deficiency syndrome: a cross-sectional study from a slum in Mumbai
}

\author{
Abhishek V. Raut* \\ Department of Community Medicine, MGIMS, Sewagram, Wardha, Maharashtra-442102, India \\ Received: 06 June 2015 \\ Revised: 15 June 2015 \\ Accepted: 13 July 2015 \\ *Correspondence: \\ Dr. Abhishek V. Raut, \\ E-mail: abhishekvraut@icloud.com \\ Copyright: (C) the author(s), publisher and licensee Medip Academy. This is an open-access article distributed under \\ the terms of the Creative Commons Attribution Non-Commercial License, which permits unrestricted non-commercial \\ use, distribution, and reproduction in any medium, provided the original work is properly cited.
}

\begin{abstract}
Background: Young people, more than any other age group, have been adversely affected by globalization, violence, advances in information and communication technology and the HIV/AIDS epidemic. The objective of the study was to assess the knowledge and epidemiological determinants related to HIV-AIDS among the youth in the urban slum.

Methods: This was a cross-sectional study conducted in Malvani slum area of Mumbai among 540 youth between 15 to 24 years of age. Two stage systematic random sampling method was used with individual household being the sampling unit.

Results: Almost everybody had heard of HIV/AIDS. 21.5\% participants had comprehensive knowledge about HIV AIDS. There were many misconceptions about how HIV-AIDS can spread. 57\% thought that HIV-AIDS could spread by kissing, $22.7 \%$ said that HIV-AIDS could spread by sharing belongings. $36.8 \%$ thought that HIV- AIDS could spread through urine while $62.6 \%$ thought HIV- AIDS to be spread by saliva. $23.9 \%$ said that withdrawing penis before ejaculation could prevent HIV-AIDS and that there was no need to use condoms in that case. The predictors for comprehensive knowledge of HIV-AIDS in study participants were religion, education and per capita income.

Conclusion: Although almost everybody had heard of HIV/AIDS, only around $21 \%$ had correct and comprehensive knowledge about HIV-AIDS. This reflects a massive gap that needs to be bridged, as awareness becomes the first step for initiating the behavior change process.
\end{abstract}

Keywords: Youth, HIV, AIDS, Comprehensive knowledge

\section{INTRODUCTION}

Youth are critical to the development of the society. They have a right, as well as duty, to be a part of this development. The international health agenda focuses on the achievement of the Millennium Development Goals (MDGs). Each of these goals is related directly or indirectly to the health and development of youth. Almost half of the current global population is under the age of 25 , making it a very youthful world. There are around 1.2 billion young people in the world today, and the next generation of youth, children less than 15 years of age will be soon a part of this vulnerable group swelling the population to 1.8 billion. Poverty, illiteracy, unemployment, armed conflict and HIV/AIDS, make a clear case for investing in young people. ${ }^{1}$ The MDGs relevant to the youth focus on youth employment, maternal health, and reduced exposure to HIV/AIDS and other preventable diseases. For the future generation of youth, the MDGs address universal primary education, reductions in child mortality, and improved maternal health. Thus in many aspects the MDGs can be considered as youth development goals. Young people, more than any other age group, have been adversely 
affected by globalization, violence, advances in information and communication technology and the HIV/ AIDS epidemic.

The youth of India, representing a fifth of our population, constitutes a vital and vibrant human resource. ${ }^{2}$ The youth population in an urban slum area is a vulnerable population where in small changes or modifications of their lifestyles done today will determine the health of these youth in the future and indirectly will reflect on the development and betterment of community. Hence we thought it prudent to assess the capacity of youth to respond to the HIV/AIDS pandemic in this study. The objective of the study was to assess the knowledge related to HIV / AIDS among the youth population in the urban slum and the epidemiological determinants for the same.

\section{METHODS}

This was a cross-sectional study conducted in Malvani slum area of Mumbai. The study population included youth between 15 to 24 years of age as per the definition of youth given by United Nations. ${ }^{3}$

Two stage systematic random sampling method was used with individual household being the sampling unit. The population of entire slum area was approximately 1,41900. The study area was divided into six areas based on the geographical boundaries. The areas were numbered from I to VI. In stage I, by using simple random sampling method, one area (Patel compound) was selected for the study purpose with approximate population of 23720 approximately and 4651 households. In stage II, every $10^{\text {th }}$ house was selected for the study purpose. The first household was selected randomly, after which every $10^{\text {th }}$ household was included in the study. Whenever a household was locked or when there were no eligible study subjects in a household the next household on the right was selected for the study purpose. The total numbers of households interviewed for the study purpose were 466 . In the 466 households 586 study subjects were found. $46(7.9 \%)$ did not give consent for interview and hence the sample size was 540. All the eligible population in a household between the age group of 15 to 24 years who were living in the study area for more than 6 months of age, were included in the study. The individuals/ eligible household members who denied giving consent for the participation in the study were excluded from the study. Ethical approval was taken from the Institutional Ethical Committee while written informed consent was taken from the youth. Data collection instrument was designed by using standard, validated questionnaires based on National Family Health Survey 2005-06. ${ }^{2}$ It was suitably modified to meet objectives and was pilottested. It contained questions on -baseline demographic information about individuals in households (age, gender, education, occupation etc), knowledge, attitudes and practices regarding HIV/AIDS. Statistical analysis were done using SPSS 16 software. Univariate and bivariate analysis was performed to find out the variables having significant associations. A multivariate logistic regression was performed to find out the predictors for comprehensive knowledge of HIV AIDS.

\section{RESULTS}

540 youths were found in the 466 household interviewed for study purpose. $37.7 \%$ of the youths were in the adolescent age group. $283(52.4 \%)$ participants were males while $257(47.6 \%)$ were females. $61.1 \%$ of the participants were Muslims, $38.1 \%$ were Hindus while other religions constituted $0.8 \%$ of study participants. 206 (38.1\%) of the participants were married. $40.3 \%$ of participants had married before $18 \mathrm{yrs}$ of age of which $81.9 \%$ were females. $32.7 \%$ of those who had married before $21 \mathrm{yrs}$ of age were males. $72.8 \%$ of the study population lived in joint families, $8.7 \%$ lived in nuclear families while $18.5 \%$ of the population was living either with some of their relatives or staying at their work place only e.g. 'jari karkhana'. $87 \%$ of those staying with relatives or at their work place didn't have a ration card. $37(6.9 \%)$ of participants were illiterate who had never gone to school. As compared to males $(34.6 \%)$ more females $(58.4 \%)$ had received primary education however $15.3 \%$ males had received higher education as compared to females. $85.6 \%$ females were unemployed while majority of males $(48.4 \%)$ were involved in semiskilled jobs.

$81.5 \%$ of the participants belonged to the poor socioeconomic class by B G Prasad's socio-economic classification while only $1.1 \%$ belonged to upper high category.

Table 1: Distribution of study participants by their knowledge about HIV-AIDS.

\begin{tabular}{|c|c|c|c|}
\hline$(\mathrm{N}=540)$ & & Frequency & $\%$ \\
\hline \multirow{2}{*}{ Heard of HIV-AIDS } & Yes & 532 & 98.5 \\
\hline & No & 8 & 1.5 \\
\hline $\begin{array}{l}\text { HIV \& AIDS are same } \\
(\mathrm{N}=532)\end{array}$ & Yes & 302 & 56.8 \\
\hline \multirow{3}{*}{$\begin{array}{l}\text { HIV-AIDS can be cured } \\
(\mathrm{N}=532)\end{array}$} & Yes & 239 & 44.9 \\
\hline & No & 266 & 48.5 \\
\hline & DK & 35 & 6.6 \\
\hline $\begin{array}{l}\text { HIV-AIDS is a fatal } \\
\text { disease }(\mathrm{N}=532)\end{array}$ & Yes & 485 & 91.2 \\
\hline $\begin{array}{l}\text { HIV-AIDS in Normal } \\
\text { looking person }(\mathrm{N}=532)\end{array}$ & Yes & 208 & 38.5 \\
\hline $\begin{array}{l}\text { HIV-AIDS and vaccine } \\
(\mathrm{N}=532)\end{array}$ & Yes & 117 & 22.0 \\
\hline $\begin{array}{l}\text { HIV-AIDS \& removal } \\
\text { from work }(\mathrm{N}=532)\end{array}$ & Yes & 228 & 42.9 \\
\hline $\begin{array}{l}\text { HIV-AIDS same as } \\
\text { malaria }(\mathrm{N}=532)\end{array}$ & Yes & 80 & 15.0 \\
\hline $\begin{array}{l}\text { HIV-AIDS hereditary } \\
(\mathrm{N}=532)\end{array}$ & Yes & 19 & 3.6 \\
\hline $\begin{array}{l}\text { HIV-AIDS Mother to } \\
\text { Child (N=532) }\end{array}$ & Yes & 506 & 95.1 \\
\hline
\end{tabular}


As shown in Table 1, $1.5 \%$ of the participants had never heard of HIV AIDS. 56.8\% thought that HIV \& AIDS were the same. $91.2 \%$ said that HIV-AIDS was a fatal disease. $38.5 \%$ thought that a normal looking person could also have HIV - AIDS. $22 \%$ of participants said that a vaccine was available for preventing HIV-AIDS. Advertisements put up in compartments of local trains and in local newspapers were the most common sources cited for their knowledge about HIV-AIDS vaccine. $42.9 \%$ of participants thought that a person having HIV or AIDS should be removed from their work. $15 \%$ of participants' thoughts that HIV-AIDS was similar to other infectious diseases like malaria or typhoid. $3.6 \%$ of participants thought of HIV-AIDS to be hereditary. $95.1 \%$ of participants were aware that HIV-AIDS could be transmitted from mother to the child during childbirth.

Table 2: Distribution of study participants by their knowledge about transmission of HIV-AIDS.

\begin{tabular}{|lllll|}
\hline (N=532) & $\begin{array}{l}\text { No } \\
\text { risk }\end{array}$ & DK & $\begin{array}{l}\text { High } \\
\text { risk }\end{array}$ & $\%$ \\
\hline Kissing & 221 & 8 & 303 & 57.0 \\
\hline Sharing belongings & 410 & 1 & 121 & 22.7 \\
\hline Unsafe needles & 31 & 3 & 498 & 93.6 \\
\hline Public toilets & 462 & 21 & 49 & 9.2 \\
\hline Sharing food & 337 & 0 & 195 & 36.7 \\
\hline Through hugging & 232 & 33 & 267 & 50.2 \\
\hline Blood donation & 73 & 12 & 447 & 84.0 \\
\hline Mosquito bite & 324 & 10 & 198 & 37.2 \\
\hline Illicit sexual intercourse & 19 & 0 & 513 & 96.4 \\
\hline Coughing & 379 & 29 & 124 & 23.3 \\
\hline Cigarettes & 403 & 15 & 114 & 21.4 \\
\hline
\end{tabular}

Table 2 gives distribution of study participants by their knowledge about transmission of HIV-AIDS. There were many misconceptions about how HIV-AIDS can spread. $57 \%$ thought that HIV-AIDS could spread by kissing. $22.7 \%$ said that HIV-AIDS could spread by using each other's belongings. $50.2 \%$ of the participants thought that HIV-AIDS could spread by hugging each other. $84 \%$ thought that HIV-AIDS could spread by donating blood while $41.7 \%$ answered that HIV-AIDS could spread by mosquito bite. $23.3 \%$ thought it to be spread by coughing while $21.4 \%$ thought that sharing common cigarettes would lead to spread of HIV-AIDS.

Table 3 shows distribution of study participants by their knowledge regarding source of infection for spread of HIV-AIDS. When asked about the infective material through which HIV-AIDS could spread 36.8\% thought that HIV- AIDS could spread through urine, 62.6\% thought HIV-AIDS to be spread by saliva, $19 \%$ each thought HIVAIDS to be spread by sweat and nasal secretions, $88 \%$ thought HIV- AIDS to be spread via breast feeding while
99.1\% and $97.7 \%$ correctly answered that HIV- AIDS could be spread by blood and semen respectively.

Table 4 shows distribution of study participants by their knowledge for prevention of HIV-AIDS. 99.6\% said that regular condom use could prevent HIV-AIDS. 99.8\% answered that avoiding sexual relation with multiple partners or CSWs could prevent HIV-AIDS. $23.9 \%$ said that withdrawing penis before ejaculation could prevent HIV-AIDS and that there was no need to use condoms in that case. $99.4 \%$ said that avoiding premarital or extramarital sexual relations would prevent HIV-AIDS while all the participants said that regular ANC checkups was a must for preventing transmission of HIV-AIDS to their child.

Table 3: Distribution of study participants by their knowledge regarding source of infection for spread of HIV-AIDS.

\begin{tabular}{|lllll|}
\hline (N=532) & $\begin{array}{l}\text { Non } \\
\text { infective }\end{array}$ & DK & Infective & $\%$ \\
\hline Semen & 4 & 8 & 520 & 97.7 \\
\hline Urine & 287 & 49 & 196 & 36.8 \\
\hline Saliva & 157 & 42 & 333 & 62.6 \\
\hline Sweat & 397 & 34 & 101 & 19.0 \\
\hline $\begin{array}{l}\text { Nasal } \\
\text { secretions }\end{array}$ & 403 & 28 & 101 & 19.0 \\
\hline Breast milk & 48 & 16 & 468 & 88.0 \\
\hline Blood & 6 & 0 & 526 & 99.1 \\
\hline
\end{tabular}

Table 4: Distribution of study participants by their knowledge for prevention of HIV-AIDS.

\begin{tabular}{|lllll|}
\hline N=532 & Yes & No & DK & $\%$ \\
\hline $\begin{array}{l}\text { Prevention - } \\
\text { condom use }\end{array}$ & 530 & 2 & 0 & 99.6 \\
\hline $\begin{array}{l}\text { Prevention - } \\
\text { sex with CSWs }\end{array}$ & 1 & 531 & 0 & 99.8 \\
\hline $\begin{array}{l}\text { Prevention - } \\
\text { coitus interruptus }\end{array}$ & 127 & 299 & 106 & 23.9 \\
\hline $\begin{array}{l}\text { Prevention - No pre / } \\
\text { extramarital sex }\end{array}$ & 529 & 1 & 2 & 99.4 \\
\hline $\begin{array}{l}\text { Prevention - } \\
\text { ANC check ups }\end{array}$ & 532 & 0 & 0 & 100.0 \\
\hline
\end{tabular}

Table 5: Distribution of the study participants by Comprehensive knowledge of HIV-AIDS.

\begin{tabular}{|lllllll|}
\hline \multirow{9}{*}{ Gender } & No & \multicolumn{4}{l}{ Yes } & \multicolumn{1}{l|}{ Total } \\
\cline { 2 - 7 } & Frequency & $\begin{array}{l}\text { Row } \\
\%\end{array}$ & Frequency & $\begin{array}{l}\text { Row } \\
\%\end{array}$ & Frequency & $\begin{array}{l}\text { Column } \\
\%\end{array}$ \\
\hline Female & 210 & 81.7 & 47 & 18.3 & 257 & 47.6 \\
\hline Male & 214 & 75.7 & 69 & 24.3 & 283 & 52.4 \\
\hline Total & 424 & 78.5 & 116 & 21.5 & 540 & 100.0 \\
\hline
\end{tabular}


In the study $116(21.5 \%)$ participants had comprehensive knowledge about HIV AIDS of these 69 (59.5\%) were males while $47(40.5 \%)$ were females as depicted in Table 5 and Figure 1.

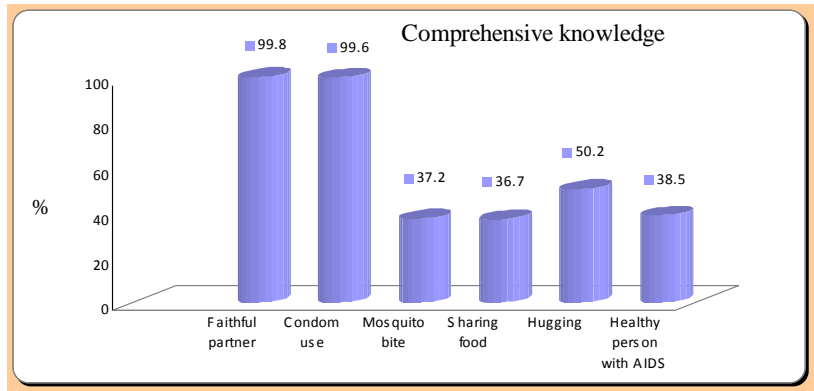

Figure 1: Comprehensive knowledge about HIV-AIDS in the participants.

$42.6 \%$ of married youth and $57.4 \%$ of unmarried youth had knowledge of HIV AIDS. The association between marriage and having comprehensive knowledge of HIV AIDS was not found to be statistically significant.

The comprehensive knowledge of the participants improved with the educational status. The association between educational status and having comprehensive knowledge of HIV AIDS was highly significant, the Chi square value was 16.5 with $\mathrm{DF}=3$ and $\mathrm{P}<0.001$. Low socioeconomic class was associated with low comprehensive knowledge of HIV-AIDS. This association was found to be statistically significant, the Chi square value was 102.4 with $\mathrm{DF}=1$ and $\mathrm{P}<0.001$.

We used logistic regression analysis to determine predictors of comprehensive knowledge. Table 6 gives predictors for Comprehensive knowledge of HIV-AIDS in the study participants. All variables were entered in model by using ENTER method in SPSS. P-value of 0.05 was considered as significant. Omnibus test for model coefficients was significant (P-value $<0.001)$. Nagelkerke R Square was 0.32 indicating that $32 \%$ variation in comprehensive knowledge can be explained by independent predictor variables viz. religion, education and per capita income. Hosmer Lemeshow goodness of fit test was non-significant $(\mathrm{P}=0.08)$ indicating that model fits the data. The predictors for comprehensive knowledge of HIV-AIDS in study participants were religion and education and per capita income at $\mathrm{P}<0.05$. Muslim religion was associated with poor comprehensive knowledge of HIV-AIDS. Hindu participants (four were non Hindus) were having 9.8 times more likelihood of having comprehensive knowledge than Muslim participants. (Odds Ratio 9.8, $95 \%$ C.I. 5.8 - 16.4). Higher education was well correlated with higher comprehensive knowledge of HIV AIDS in study participants by 14.1 times. Participants who belonged to non-poor socioeconomic class had 2 times greater chances of having comprehensive knowledge than who belonged to poor class (Odds Ratio 2.0, $95 \%$ C.I. $1.1-3.6)$.

Table 6: Predictors for Comprehensive knowledge of HIV-AIDS in the study Participants.

\begin{tabular}{|lclllll|}
\hline Variables & B & S.E. & Sig. & Exp (B) & $\begin{array}{l}\text { Ex.0\% (B) C.I. for } \\
\text { Lower }\end{array}$ & Upper \\
\hline Gender & -0.067 & 0.284 & 0.814 & 0.935 & 0.536 & 1.632 \\
\hline Religion & 2.284 & 0.263 & $\mathbf{0 . 0 0 0}$ & 9.817 & 5.858 & 16.451 \\
\hline $\begin{array}{l}\text { Educational } \\
\text { status }\end{array}$ & 2.651 & 1.029 & $\mathbf{0 . 0 1 0}$ & 14.174 & 1.887 & 106.447 \\
\hline $\begin{array}{l}\text { Per capita } \\
\text { income }\end{array}$ & 0.724 & 0.285 & $\mathbf{0 . 0 1 1}$ & 2.062 & 1.179 & 3.606 \\
\hline Marital status & 0.337 & 0.278 & 0.225 & 1.401 & 0.812 & 2.418 \\
\hline Constant & -5.325 & 1.061 & 0.000 & 0.005 & & \\
\hline
\end{tabular}

\section{DISCUSSION}

In a study by Joshi et al, regarding HIV not only they had poor knowledge but $10-20 \%$ of these adolescents had a number of myths and misconceptions such as HIV/AIDS could spread by eating unclean food, by mosquito bites, by sharing toilets or utensils and cloth of infected person. Only $30-40 \%$ of younger adolescent had correct knowledge on how HIV/AIDS spreads and only 20-40\% of adolescent knew how it could be prevented. ${ }^{4}$ Benera et al, conducted a study in Delhi to assess the knowledge of undergraduates on AIDS. About $60.8 \%$ and $72.5 \%$ knew AIDS could be prevented by using condom and having one faithful partner respectively, nearly $57.5 \%$ knew AIDS was incurable and $62.8 \%$ knew that using disposable needle prevents AIDS. About 58\% wrongly stated that AIDS could be transmitted by shaking hands, using toilets, breathing too close, and use of same glass. ${ }^{5}$

The findings in our study are in accordance with the findings of the above discussed two studies. In the present study, it was found that $56.8 \%$ of the participants thought that HIV \& AIDS were the same. $22 \%$ of participants said that a vaccine was available for preventing HIV-AIDS. $42.9 \%$ of participants thought that a person who had HIV or AIDS should be removed from their work. $15 \%$ of participants' thought that HIV-AIDS was similar to other infectious diseases like malaria or typhoid. $3.6 \%$ of participants thought of HIV-AIDS to be hereditary.

As per the NFHS 3 data less than half of women aged 1549 (47 percent) and almost two-thirds of men (63 percent) in India knew that HIV can be transmitted from a mother to her baby, but only one-fifth of women and men knew that the risk of such transmission can be reduced with the use of certain drugs. ${ }^{2}$ In our study we found that $95.1 \%$ of participants were aware that HIVAIDS could be transmitted from mother to the child during child birth. 
In a study conducted by Francis et al, the level of knowledge of AIDS was high, though $41 \%$ thought that AIDS can be acquired by donating blood, $27 \%$ thought kissing spreads the infection and 36\% thought AIDS is curable. ${ }^{6}$ In study by Friensen et al, in high school students in Papua New Guinea found that over $98 \%$ knew what AIDS and HIV were. 97\% knew that HIV was sexually transmitted, but many misconceptions existed, one third thought that HIV was transmitted by mosquitoes, $7 \%$ that HIV infected persons were a danger in the classroom. $72 \%$ knew that using a condom at every sexual encounter was away of protection from HIV infection. ${ }^{7}$

In our study also we found that there were many misconceptions about how HIV-AIDS could spread. 57\% thought that HIV-AIDS could spread by kissing. $22.7 \%$ said that HIV-AIDS could spread by using each other's belongings. $84 \%$ thought that HIV-AIDS could spread by donating blood while $41.7 \%$ answered that HIV-AIDS spreads by mosquito bite. $23.3 \%$ thought it to be spread by coughing while $21.4 \%$ thought that sharing common cigarettes would lead to spread of HIV-AIDS.

Comprehensive knowledge about HIV-AIDS is defined as: 1) knowing that both condom use and limiting sex partners to one uninfected faithful partner are HIV/AIDS prevention methods; 2) being aware that a healthy-looking person can have HIV/AIDS; and 3) rejecting the two most common misconceptions in India - that HIV/AIDS can be transmitted through mosquito bites and by sharing food. NFHS-3 results revealed that only 17 percent of women and 33 percent of men in India had comprehensive knowledge of HIV/AIDS prevention and transmission. ${ }^{2}$ The proportions of women and men who rejected all three most common misconceptions, who knew that a healthylooking person could have HIV/AIDS, or who have comprehensive knowledge about HIV/AIDS decreased with age. Nearly two-fifths of women (37 percent) aged 15-24 had sufficient knowledge to reject all three most common transmission misconceptions, but this percentage declined with age to 24 percent among women aged 40-49. In fact, correct knowledge as measured by all indicators declined with age for both women and men. Among men, the level of comprehensive knowledge varied from 8 percent among those with no education to 62 percent among those with at least 12 years of education. ${ }^{2}$ In our study we found that $116(21.5 \%)$ participants had comprehensive knowledge about HIV AIDS of these 69 $(59.5 \%)$ were males while $47(40.5 \%)$ were females. The comprehensive knowledge about HIV-AIDS showed significant association with factors like education, religion, socio-economic status. In our study we found that $42.6 \%$ of married youth and $57.4 \%$ of unmarried youth had knowledge of HIV AIDS. The association between marriage and having comprehensive knowledge of HIV AIDS was not found to be statistically significant. The association between religion and having comprehensive knowledge of HIV AIDS was highly significant.

\section{CONCLUSION}

It was evident that despite the intensive campaigns for creating awareness related to HIV-AIDS there is a substantial gap that needs to be bridged. Alternative approaches need to be tapped for percolating the messages to the vulnerable youth population in a slum if we intent to prevent them for indulging in high-risk behavior. The youth need to be provided with correct knowledge and enabling environment for behavior change, to stop their undesirable practices and lead them to the road to healthy life.

\section{ACKNOWLEDGEMENTS}

Dr S.R. Suryawanshi, Professor and Head, Dept. of Preventive and Social Medicine, TN Medical College, Mumbai, for guiding me to complete this research work. Dr A.P. Pakhare, Assistant Professor, Dept. of Community Medicine and Family Medicine, AIIMS, Bhopal, for helping me out with the analysis.

Funding: No funding sources Conflict of interest: None declared

Ethical approval: The study was approved by the Institutional Ethics Committee

\section{REFERENCES}

1. United Nations. 2006. World Youth Report 2005. Dept. of Economic and Social Affairs, United Nations, New York.

2. International Institute for Population Sciences (IIPS) and Macro International. 2007. National Family Health Survey (NFHS-3), 2005-06: India: Volume II. Mumbai: IIPS.

3. United Nations. 2008. World Youth Report 2007. Dept. of Economic and Social Affairs, United Nations, New York.

4. Joshi B N, Chauhan S L, Bhadoria V, Tryambake V, Gaikwad N, Ghule M. Reproductive health problems and help seeking behavior among adolescents in urban India, Indian Journal of Pediatrics, Volume 73, Number 6 / June, 2006, 509-513.

5. Benara SK, Khalucha RK, Chaudhury BN, Ramaswamy J, Bhattacharyya J, Chawala U. AIDS: a survey of knowledge, attitudes and beliefs of undergraduate students of Delhi University. Indian Journal of Community Medicine. 1992;17(4):155-9.

6. Francis PT, Gill JS, Choudhary S. Knowledge, behaviour and attitude regarding AIDS, STDs, human sexuality among senior students in Delhi, Indian Journal of Community Medicine, 1994; January - March.

Cite this article as: Raut AV. Youth and human immunodeficiency virus infection and acquired immune deficiency syndrome: a cross-sectional study from a slum in Mumbai. Int J Community Med Public Health 2015;2:293-7. 